\title{
Sharia in het Westen (II) ${ }^{*}$
}

Maurits Berger

In dit artikel onderneem ik de poging om een samenvattend model te ontwikkelen van het begrip 'sharia in het Westen'. Dit model is opgebouwd uit drie onderdelen. Het eerste onderdeel betreft de vraag 'wat is sharia?' en bespreekt de manieren waarop sharia wordt toegepast door Westerse moslims en de domeinen waarin ze dit doen. Dit onderdeel is vorig jaar in nummer3 van dit tijdschrift besproken. Het tweede onderdeel van het model betreft de vraag 'wat is het Westen?' en bespreekt de Westerse omgeving waarin de 'sharia' actief is en de Westerse reacties op deze sharia. Het eerste en tweede deel van het model kunnen we beschouwen als actie en reactie, en het derde deel vormt de synthese daarvan: wat is de respons van de moslims? Het tweede deel ('Het Westen') en het derde deel ('Reacties van moslims') zijn het onderwerp van het onderhavige artikel.

\section{Deel II Het Westen}

We komen nu toe aan het tweede onderdeel van het model, waarin we 'het Westen' identificeren, alsmede de aard van de Westerse reacties op de regels van de islam zoals die worden nageleefd door moslims in het Westen.

\section{Definitie van het Westen}

Het begrip 'het Westen' is nogal eigenaardig. Als we het bezien als geografische aanduiding, dan is het onjuist wanneer bijvoorbeeld Australië, Japan, Zuid-Afrika of Zuid-Amerika daar ook onder zou vallen. En als we de term gebruiken als een bepaald waardesysteem dat overal in de wereld van toepassing zou kunnen zijn, dan is het nogal verwarrend om daar een geografische aanduiding voor te gebruiken. Niettemin is het gebruik van de term 'het Westen' zo ingeburgerd, vooral in verband met het begrip sharia, dat we het niet kunnen omzeilen.

Voor dit model definieer ik het Westen als een geografische regio die een bepaalde geschiedenis, kenmerken en waarden deelt. Met de geschiedenis bedoel ik een gedeeld historisch erfgoed van Europese oorsprong, waarvan het christelijke erfgoed een belangrijk kenmerk is. ${ }^{1}$ De erosie van deze religieuze erfenis door een proces van secularisatie is de tweede eigenschap die de meeste landen in het Westen delen. Het begrip secularisme wordt als een belangrijke Westerse waarde ingeroepen, met name in reactie op de aanwezigheid van de islam in Westerse

* Dit is het tweede deel van de bewerkte vertaling van 'Understanding sharia in the West' dat is verschenen in Journal of Law, Religion and State 2018, 6, p. 236-273. Het eerste deel verscheen in het Tijdschrift voor Religie, Recht en Beleid 2019, 3, p. 17-31.

1 Een kritische historische analyse is te vinden in M.A. Perkins, Christendom And European Identity, The Legacy of a Grand Narrative since 1789, 2004. Voor een meer intellectuele historische benadering, zie L. Siedentop, Inventing the Individual. The Origins of Western Liberalism, 2014. 
samenlevingen. ${ }^{2}$ Met het derde kenmerk, namelijk de waarden die Westerse landen delen, doel ik op bepaalde beginselen die zijn vastgelegd in grondwetten en conventies, zoals politieke (democratie, liberalisme, politieke vrijheden) en juridische (rechtsstaat, grondwettelijke rechten, mensenrechten) beginselen.

Binnen de context van deze gedeelde kenmerken zijn er ook duidelijke verschillen tussen Westerse landen. Hierbij kunnen we denken aan de nationale verschillen in ervaringen met moslimgemeenschappen en immigranten, in de politieke en juridische systemen en in de houding ten opzichte van religie. In landen in Zuidoost-Europa bijvoorbeeld, zijn moslims en de islamitische infrastructuur een eeuwenoud verschijnsel, terwijl in andere Westerse landen de aanwezigheid van moslims van recente datum is. Westerse landen zijn het onderling eens over begrippen als vrijheid van godsdienst, maar kunnen deze op uiteenlopende wijzen interpreteren. Dat is de reden waarom het Europees Hof voor de Rechten van de Mens (EHRM) gebruikmaakt van het begrip margin of appreciation ${ }^{3}$ En later in dit artikel zullen we zien dat West-Europa en de Verenigde Staten het weliswaar eens zijn over het begrip secularisme als belangrijkste waarde, maar zeer verschillende interpretaties hanteren voor de betekenis ervan. Deze verschillen zijn derhalve niet meer dan nationale of culturele inkleuringen van de kenmerken die Westerse landen gemeenschappelijk hebben.

Op grond van deze kenmerken is een regionale aanduiding van 'het Westen' eigenlijk niet meer nodig. Toch doe ik dat wel, omdat bepaalde regio's meer onderling verweven zijn doordat hun regeringen in regionale overlegorganen zitten, er sprake is van handel en andere vormen van uitwisseling, en de bevolkingen elkanders nieuws volgen. Op allerlei terreinen - en dus ook in de reactie op regels van de islam - houden deze landen elkaar nauwlettend in het oog, voeren overleg, en proberen soms gezamenlijk op te trekken. Om die reden hanteer ik persoonlijk een beperkte definitie van het Westen die alleen Europa en NoordAmerika omvat. Andere definities zijn echter ook mogelijk en die omvatten bijvoorbeeld Zuid-Amerika, Australië en wellicht Rusland, Israël en Zuid-Afrika. Een strikte regionale afbakening is echter niet mogelijk en ook niet wenselijk, omdat de onderzoeker de ruimte moet hebben om zelf de parameters van het onderzoeksterrein te stellen.

\section{Twee Westerse reacties op de 'sharia'}

Als we een lijst zouden opstellen van islamitische regels die door moslims in het Westen worden toegepast en elke regel zouden confronteren met de vraag 'Laten Westerse waarden deze islamitische regel toe of niet, en waarom?', dan zouden we een uiteenlopende reeks aan antwoorden krijgen. Ten eerste omdat er verschillen zijn tussen de Westerse landen. In sommige Westerse landen mogen politieagen-

2 J. Cesari \& S. McLoughlin, European Muslims and the Secular State, 2005; S. Bracke \& N. Fadil, Islam and Secular Modernity under Western Eyes: A Geneaology of a Constitutive Relationship, 2008.

3 T. Lewis, 'What Not to Wear: Religious Rights, the European Court, and the Margin of Appreciation', The International and Comparative Law Quarterly 2007, 395; R. Nigro, 'The Margin of Appreciation Doctrine and the Case-Law of the European Court of Human Rights on the Islamic Veil', Human Rights Review 2010, 531; J. Gerards, 'Pluralism, Deference and the Margin of Appreciation', European Law Journal 2011, 80. 
ten en leraren bijvoorbeeld een hoofddoek dragen, terwijl dit in andere landen strikt verboden is. Ten tweede roepen de verschillende regels van de islam verschillende reacties op: sommige regels worden vanuit Westers perspectief als controversieel beschouwd, zoals gezichtssluiers en bepaalde vormen van familierecht, terwijl andere niet als probleem worden gezien, zoals ritueel begraven, of zelfs worden omarmd, zoals islamitisch bankieren. ${ }^{4}$

Binnen deze vele en vaak tegenstrijdige Westerse reacties kunnen we echter twee brede categorieën van reacties onderscheiden. De eerste noem ik de 'politiek-juridische reactie', die overeenkomt met alle normen die voortkomen uit wetgeving en rechterlijke uitspraken en die kan worden geparafraseerd als 'dit is hoe we onze samenleving hebben georganiseerd'. De tweede noem ik de 'cultureel-religieuze reactie', wat overeenkomt met alle politieke, culturele en sociale normen die worden gedeeld door de meerderheid van de samenleving en die kan worden geparafraseerd als 'zo doen we het hier'. Als we door de lens van deze twee reacties kijken, krijgen we een scherp beeld van het Westen en zijn interactie met de regels van de islam.

\subsection{Politiek-juridische reactie}

Westerse landen delen een systeem van politieke en burgerlijke vrijheden en instituties, zoals rechtsstaat, democratie, mensenrechten en (individuele) vrijheden, die grotendeels zijn vastgelegd in grondwetten en verdragen. De reacties die deze politieke en juridische waarden oproepen in geval van islamitische regels dienen we te bezien in de bredere context van de Westerse politiek-juridische reactie op religie in het algemeen. Hoewel recente publicaties wijzen op verschuivingen in het juridische paradigma als gevolg van opkomende culturele en religieuze pluriformiteit, ${ }^{5}$ kunnen we niettemin een paar basiskenmerken van deze reactie onderscheiden die van structurele aard zijn. ${ }^{6}$

De belangrijkste van deze kenmerken is dat religie in Westerse landen ondergeschikt is aan de algemene politieke en juridische nationale structuur. Politieke en juridische begrippen zoals vrijheid van religie en scheiding van kerk en staat zijn vooral middelen om de rol van religie in een bepaalde samenleving te reguleren. Overigens geldt ook hier dat landen kunnen verschillen in de manier waarop zij dat doen. Godsdienstvrijheid betekent bijvoorbeeld in sommige landen de afwezigheid van statelijke betrokkenheid, terwijl in andere landen juist sprake is van actieve staatssteun om deze vrijheid te garanderen. In het laatste geval is bijvoorbeeld formele staatserkenning van een religieuze gemeenschap nodig, zodat deze gemeenschappen theologiefaculteiten kunnen oprichten (zoals bijvoorbeeld in Duitsland) of staatsgelden kunnen ontvangen om de salarissen van hun geestelij-

4 Deze paradox wordt 'goede sharia - slechte sharia' genoemd; A. Black \& K. Sadiq, 'Good and Bad Sharia: Australia's Mixed Response to Islamic Law', UNSW Law Journal 2011, 383.

5 Zie bijv. R. Grillo e.a., Legal Practice and Cultural Diversity, 2009; J.S. Nielsen \& L. Christoffersen (red.), Shari'a As Discourse. Legal Traditions and the Encounter with Europe, 2010; P. Shah, M.-C. Foblets \& M. Rohe (red.) Family, Religion and Law: Cultural Encounters in Europe, 2014.

6 Ch.N. Doe, 'A Sociology of Law on Religion Towards a New Discipline: Legal Responses to Religious Pluralism in Europe', Christian Law Review 2004, 68. 
ken te betalen (bijvoorbeeld in België, Bosnië), of om erkend te worden als een formele gesprekspartner van de staat (meeste Westerse landen).

Ondanks deze vormen van staatsregulering hebben gevestigde religieuze gemeenschappen in Westerse samenlevingen vaak hun institutionele en juridische infrastructuur behouden. Deze structuren bestaan parallel aan die van de staat en worden toegestaan uit hoofde van hun godsdienstvrijheid. ${ }^{7}$ Bijgevolg hebben katholieke, protestantse, orthodoxe en joodse gemeenschappen in de meeste Westerse landen hun eigen religieuze 'rechtbanken' die hun religieuze familiezaken autonoom regelen, buiten het rechtsstelsel van de staat om. In de meeste Westerse landen hebben hun beslissingen echter geen rechtsmacht, zodat hier sprake is van een mate van onderlinge vrijwilligheid (waarbij groepsdruk een aanzienlijke rol kan spelen, zoals we eerder al zagen).

\subsection{Cultureel-religieuze reactie}

Veel controverses met betrekking tot de regels van de islam in Westerse samenlevingen zijn echter niet van politiek-juridische aard, maar worden vooral ingegeven door maatschappelijke en culturele bezwaren. Dit is de 'cultureel-religieuze reactie', die niet zo eenvoudig gedefinieerd kan worden als de politiek-juridische reactie, aangezien de religieuze en culturele waarden verankerd zijn in de gewoonten en tradities van een samenleving.

Een voorbeeld is secularisme. Dat wordt in Westerse samenlevingen vaak aangehaald als een fundamentele waarde die zich zou verzetten tegen de publieke manifestaties van de islam in het Westen. ${ }^{8}$ Ik zou echter menen dat hier niet zozeer sprake is van secularisme als een politiek-juridische waarde, maar als een culturele traditie van het omgaan met religie. Deze traditie kan enorm verschillen van land tot land, ook al zijn al die landen stellig over het belang van secularisme. Zo heeft in de meeste Europese landen het begrip secularisme zich ontwikkeld tot een dominante publieke en politieke cultuur die de invloed en zelfs manifestatie van religiositeit in beginsel afwijst (hierop bestaan allerlei uitzonderingen en nuances, maar dit terzijde). Dit staat in contrast met bijvoorbeeld de Verenigde Staten, waar eveneens grote waarde wordt toegekend aan secularisme, maar waar

7 Zie voor Nederland M. Berger, 'Shariarechtbanken en religieuze familierechtspraak in Nederland’, Tijdschrift voor Religie, Recht en Beleid 2010, 2, p. 49. Zie voor Groot-Brittannië R. Sandberg e.a., 'Britain's Religious Tribunals: 'Joint Governance' in Practice', Oxford Journal of Legal Studies 2013, 263.

8 T. Asad, Formations of the Secular: Christianity, Islam, Modernity, 2003; Cesari \& McLoughlin 2005; J. Casanova, 'Religion, European secular identities, and European integration', Transit 2004, 1; O. Roy, Secularism confronts Islam, 2007; A. Salvatore, 'Power and Authority within European Secularity: From the Enlightenment Critique of Religion to the Contemporary Presence of Islam', Muslim World (special edition 'Islam and Authority in Europe) 2006, 543. 
religie een prominente rol speelt in het publieke en politieke domein. ${ }^{9}$ Manifestaties van religie, of het nu gaat om islam of een andere religie, zullen daarom eerder botsen met de Europese manier van omgaan met religie dan de manier van de Amerikanen.

Deze confrontatie is echter veel minder prominent wanneer secularisme wordt bezien als het politiek-juridische instrument bedoeld voor de scheiding van staat en religie. Het is precies deze scheiding die door veel Europese moslims wordt omarmd omdat het hen vrijheid garandeert om hun geloof te oefenen volgens hun eigen wensen en zonder staatsinmenging. ${ }^{10}$ Dit verschil tussen de politiekjuridische en cultureel-religieuze opvatting van secularisme verklaart hoe secularisme in Europa wordt aangehaald als belangrijk instrument om religie buiten de politiek te houden, maar tegelijkertijd waarom verschillende Europese regeringsleiders in 2005 voorstelden om in het Verdrag betreffende de Europese Unie te laten opnemen dat de Europese waarden van joods-christelijke aard zijn. ${ }^{11}$

\section{De twee reacties waren van toepassing: Westen versus sharia}

Het onderscheid tussen de politiek-juridische en cultureel-religieuze reacties helpt ons de verschillende en soms tegengestelde reacties op de regels van de islam te begrijpen. Deze verschillende reacties zien we tussen verschillende landen, maar ook binnen dezelfde samenleving. Om enkele voorbeelden te noemen: de wet staat het bouwen van moskeeën toe, terwijl daar brede oppositie tegen kan bestaan in de samenleving; manieren van groeten zijn niet wettelijk geregeld, maar het niet willen schudden van handen kan in de betreffende maatschappij worden opgevat als uitermate beledigend; in landen als Kosovo en Albanië is het dragen van de hoofddoek niet toegestaan aan universiteiten, maar wordt het wel geaccepteerd als onderdeel van de nationale cultuur van deze landen. Overigens zijn de politiek-juridische en cultureel-religieuze reacties niet altijd tegengesteld; soms komen ze overeen, zoals rentevrije 'islamitische' transacties die zowel juridisch mogelijk zijn als breed worden geaccepteerd in Westerse landen, en polygamie, die zowel wettelijk als cultureel niet acceptabel is in Westerse samenlevingen.

Aan de hand van dergelijke voorbeelden kunnen we een matrix opstellen die elke regel van de islam identificeert op basis van (wel of niet) worden toegestaan

9 Voor vergelijkende analyses zie o.a. P.L. Berger, G. Davie \& E. Fokkas, Religious America, Secular Europe?: A Theme and Variation, 2008; J. Cesari, When Islam and Democracy Meet: Muslims in Europe and the United States, 2004; B.D. Metcalf, Making Muslim Space in North America and Europe, 1996; P.I. Jackson \& P.A. Zervakis, The Integration of Muslims in Germany, France and the United States: Law, Politics and Public Policy (annual meeting of the American Sociological Association), 2004, http://citation.allacademic.com/meta/p_mla_apa_research_citation/1/0/9/2/3/ p109230_index.html.

10 J. Klausen, The Islamic Challenge: Politics and Religion in Western Europe, 2005, p. 204 e.v.

11 M. Heyward, 'What Constitutes Europe?: Religion, Law and Ideology in the Draft Constitution for the European Union', Hanse Law Review 2005, p. 227-235; I. Bărbulescu \& G. Andreescu, 'References to God and the Christian Tradition in the Treaty Establishing a Constitution for Europe: An Examination of the Background, Journal for the Study of Religions and Ideologies 2009, 24, p. 207-223. 
volgens politiek-juridische waarden, en (wel of niet) worden geaccepteerd volgens cultureel-juridische waarden (zie tabel 1).

\section{Tabel 1}

\begin{tabular}{|c|c|c|c|}
\hline $\begin{array}{l}\text { Voorbeelden van } \\
\text { islamitische regels }\end{array}$ & $\begin{array}{l}\text { Toegestaan (poli- } \\
\text { tiek-juridische reac- } \\
\text { tie) }\end{array}$ & $\begin{array}{l}\text { Geaccepteerd } \\
\text { (cultureel-reli- } \\
\text { gieuze reactie) }\end{array}$ & Westerse landen \\
\hline Ritueel begraven & Ja (expliciet)* & $\mathrm{Ja}$ & meeste Westerse landen \\
\hline \multirow[t]{2}{*}{ Ritueel slachten } & Ja (expliciet) & $?$ & meeste Westerse landen \\
\hline & Nee (expliciet) & $?$ & $\begin{array}{l}\text { o.a. Denemarken, Zwitser- } \\
\text { land, Polen }\end{array}$ \\
\hline \multirow[t]{2}{*}{ Vorm van moskee } & Ja (expliciet) & Nee & meeste Westerse landen \\
\hline & Nee (expliciet) & Nee & Zwitserland (t.a.v. minaret) \\
\hline \multirow[t]{2}{*}{ Sharia-'rechtbank' } & Ja (expliciet) & $\mathrm{Ja}$ & $\begin{array}{l}\text { Griekenland (West- } \\
\text { Thracië) }\end{array}$ \\
\hline & Nee (expliciet) & Nee & meeste Westerse landen \\
\hline \multirow[t]{2}{*}{ Shariacouncil } & Ja (expliciet) & Nee & Verenigd Koninkrijk \\
\hline & Ja (impliciet) & Nee & meeste Westerse landen \\
\hline \multirow{2}{*}{$\begin{array}{l}\text { Gezichtssluier } \\
\text { (boerka) }\end{array}$} & Ja (impliciet) & Nee & meeste Westerse landen \\
\hline & Nee (expliciet) & Nee & $\begin{array}{l}\text { o.a. Frankrijk, Nederland, } \\
\text { België, Denemarken }\end{array}$ \\
\hline $\begin{array}{l}\text { Geen handen schud- } \\
\text { den }\end{array}$ & Ja (impliciet) & Nee & meeste Westerse landen \\
\hline \multirow[t]{2}{*}{ Islamitisch testament } & Ja (impliciet) & $\mathrm{Ja}$ & o.a. Verenigd Koninkrijk \\
\hline & & Nee & o.a. Nederland \\
\hline \multirow{2}{*}{$\begin{array}{l}\text { Hoofddoek op univer- } \\
\text { siteit }\end{array}$} & $\mathrm{Ja}$ & $\mathrm{Ja}$ & meeste Westerse landen \\
\hline & Nee (expliciet) & $\mathrm{Ja}$ & o.a. Albanië, Kosovo \\
\hline \multirow{2}{*}{$\begin{array}{l}\text { Hoofddoek als politie- } \\
\text { uniform }\end{array}$} & Nee (expliciet) & Nee & meeste Westerse landen \\
\hline & Ja (expliciet) & $\mathrm{Ja}$ & Verenigd Koninkrijk \\
\hline Islamitisch bankieren & Ja (impliciet) & $\mathrm{Ja}$ & meeste Westerse landen \\
\hline Polygamie & Nee (expliciet) & Nee & meeste Westerse landen \\
\hline \multirow[t]{2}{*}{ 'Sharia' } & Ja (impliciet) & Nee & $\begin{array}{l}\text { Aartsbisschop van Canter- } \\
\text { bury; Lord Chief Justice of } \\
\text { England }\end{array}$ \\
\hline & Nee (expliciet) & Nee & $\mathrm{ECHR}$; diverse staten in VS \\
\hline
\end{tabular}

\footnotetext{
* Expliciet versus impliciet: een wet kan expliciet een regel van de islam vermelden (bijvoorbeeld het boerkaverbod in Frankrijk of het verbod op rituele slachtingen in Denemarken), of kan impliciet een dergelijke regel toestaan (islamitisch bankieren maakt bijvoorbeeld deel uit van de contractvrijheid).
}

Deze matrix van politiek-juridische en cultureel-religieuze antwoorden is niet volledig, want is vooral illustratief bedoeld. Bovendien ontbeert het de nodige 
nuance. Vooral het normatieve aspect van de cultureel-religieuze dimensie verdient een complexer antwoord dan een eenvoudig ja of nee. Maar de matrix helpt ons om Westerse reacties op 'sharia' te begrijpen. We zien namelijk dat nogal wat regels van de islam twee tegengestelde antwoorden krijgen van hun Westerse omgeving: ze kunnen expliciet of impliciet worden toegestaan door de wet, maar tegelijkertijd niet aanvaardbaar worden geacht vanuit een cultureel, religieus of sociaal perspectief. Dit verklaart de verwarring in discussies, wanneer het vaak gehoorde argument 'dat mag toch niet!' lijkt te verwijzen naar een wettelijk verbod, terwijl het in de praktijk vaak gaat om gewoontes en omgangsvormen. Het politiek-juridische 'dat niet is toegestaan' wordt dan vermengd met het cultureelreligieuze antwoord 'zo doen we dat niet, hier'. Enkele voorbeelden kunnen dit verduidelijken.

Het eerste voorbeeld is dat van de shariarechtbanken. De enige shariarechtbanken die deel uitmaken van het nationale rechtssysteem in het Westen bestaan in de Griekse provincie West-Thracië. ${ }^{12}$ Gezien de langdurige aanwezigheid van protestantse, katholieke en joodse religieuze 'rechtbanken'13 in Westerse samenlevingen, lijkt het erop dat vanuit politiek-juridisch oogpunt een islamitisch tribunaal aanvaardbaar zou moeten zijn. Maar de cultureel-religieuze reactie op islamitische tribunalen is de dominante. Het is opmerkelijk dat de argumenten tegen dergelijke 'shariarechtbanken' zelden worden gebruikt tegen de religieuze tribunalen van de andere religies. ${ }^{14}$

Een ander voorbeeld is het zogenoemde boerkaverbod, ofwel het verbod op het dragen van de gezichtssluier in het publieke domein. Hiertoe zijn wettelijke verboden ingesteld in onder andere Frankrijk (2010), België (2011) en Nederland (2018). De door de wetgever aangevoerde redenen voor zo'n verbod zijn vrij divers, inclusief politiek-wettelijke waarden als gelijkheid, vrijheid en menselijke waardigheid, maar hebben vooral betrekking op cultureel-religieuze bezwaren zoals 'afwijzing van de samenleving', 'problematisch voor integratie', 'boerka's worden niet genoemd in de Koran', 'onderdrukking van vrouwen' en 'verstoring van de openbare orde'. ${ }^{15}$ De critici van een dergelijk verbod baseerden zich uitslui-

12 Zie M. Berger, De laatste Shariarechtbank van Europa, Den Haag: Boom juridisch 2019.

13 De term 'rechtbank' wekt de indruk dat het zou gaan om rechtssprekende instellingen die door de staat erkend zijn, wat niet het geval is. Tribunaal of geschillencommissie zou een meer accurate term zijn.

14 Een illustratief geval is Ontario, waar familiale arbitragetribunalen voor joden, christenen en andere religieuze en inheemse gemeenschappen hadden bestaan, maar in 2007 werden ingetrokken na langdurige discussies over de aard van dergelijke tribunalen toen moslims ook een soortgelijk tribunaal wilden oprichten. Zie Bakht, 'Family Arbitration Using Sharia Law: Examining Ontario's Arbitration Act and its Impact on Women', Muslim World Journal of Human Rights 2004, 1; M. Boyd, Dispute Resolution in Family Law: Protecting Choice, Promoting Inclusion (Review Report to the Attorney General and Minister Responsible for Women's Issues), Ontario 2004, www.attorneygeneral.jus.gov.on.ca/english/about/pubs/boyd/executivesummary.pdf;

S.H. Razack, "The "Sharia Law Debate" In Ontario: The Modernity/Premodernity Distinction In Legal Efforts To Protect Women From Culture', Feminist Legal Studies 2007, 3.

15 M.S. Berger, 'Rechtsgronden voor een verbod op het gezichtsbedekkende sluier in Frankrijk, België en Nederland', Tijdschrift voor Religie, Recht en Beleid 2010, p. 96. Het aantal vrouwen dat dergelijke volledige gezichtssluiers draagt, werd geschat op 250 in België (13 miljoen inwoners), 400 in Nederland (17 miljoen inwoners) en tussen 400 en 2.000 in Frankrijk (66 miljoen inwoners). 
tend op politiek-juridische termen (schending van individuele autonomie en gelijke behandeling), ${ }^{16}$ maar het cultureel-religieuze argument bleek beslissend: zo doen we dat niet, hier. ${ }^{17}$

Een laatste voorbeeld is het verbod op 'sharia' als zodanig. Hiervoor hebben we al de opvattingen van het Europese Hof voor de Rechten van de Mens over 'sharia' besproken. Verschillende Amerikaanse staten gingen echter een stap verder door 'sharia' als zodanig te verbieden. Dit begon met het wetsvoorstel met de veelzeggende titel 'Save our State' in Oklahoma, in 2010. ${ }^{18}$ Vervolgens waren er staten die expliciet verboden dat 'shariarecht' (sharia law) door hun rechtbanken zou worden toegepast; ${ }^{19}$ andere staten pasten een algemener verbod op religieuze of buitenlandse wetten toe, en een derde categorie van staten verboden buitenlandse wetten die niet dezelfde bescherming bieden als Amerikaanse wetgeving. ${ }^{20}$ Twee kwesties zijn hierbij opvallend. Ten eerste definieert geen van deze staten wat ze bedoelen met 'sharia'. Ten tweede is juist in deze staten nauwelijks sprake van enige moslimaanwezigheid, en evenmin hebben zij ooit te maken gehad met sharia of enige islamitische regel: 'sharia' was blijkbaar niet zozeer een praktijk die gestopt moest worden, maar die bij voorbaat verhinderd diende te worden. ${ }^{21}$ Hoewel de politiek-juridische reactie (vrijheid van godsdienst, rechtsstaat, rechtsgelijkheid) tegen een dergelijk verbod zou zijn, werden deze argumenten tenietgedaan door de cultureel-religieuze reactie.

\section{De twee reacties gecombineerd: meerderheidscontrole}

De combinatie van de twee Westerse reacties laat zien dat de discussies over de sharia gaan over meer dan wetgeving en juridische waarden. Maar deze reacties laten nog iets anders zien. $\mathrm{Zij}$ vertegenwoordigen namelijk een normatief systeem dat wordt gehandhaafd door middel van politieke, wettelijke en sociale meerderheidscontrole, waarbij de term 'meerderheidscontrole' verwijst naar het feit dat

16 Deze oppositie werd in Frankrijk en Nederland bijv. verwoord door respectievelijk de Conseil d'Etat, 'Etude relatieve aux mogilités juridiques d'interdiction du port du voile integral', 25 maart 2010, www.conseil-etat.fr/cde/media/document/avis/etude_vi_30032010.pdf, en de Raad van State, RvS 21 september 2007, W03.07.0219 / II.

17 Het Europees Hof voor de Rechten van de Mens erkende de Franse en Belgische verboden in respectievelijk 2014 en 2017 op basis van het principe van 'samenleven' (zie voor Frankrijk SAS/ Frankrijk, 1 juli 2014, en voor België Belcacemi en Oussar/België en Dakir/België, beide 11 juli 2017).

18 H.R.J Res. 1056, 52e Leg., 2d Reg. Sess. (Okl. 2010).

19 In 2020 waren dit de staten Alabama, Arizona, Kansas, Louisiana, North Carolina, South Dakota, Tennessee en Texas. Er waren andere staten die vergelijkbare wetten hadden aangenomen, maar die werden voor de rechtbank vernietigd.

20 M. Elsayed, 'Contracting Into Religious Law: Anti-Sharia Enactments And The Establishment And Free Exercise Clauses', Geo. Mason Law Rev 2013, p. 943-944; S.M. Rosato, 'Saving Oklahoma's "Save Our State" Amendment: Sharia Law In The West And Suggestions To Protect Similar State Legislation From Constitutional Attack', Setton Hall Law Review 2014, 659, p. 685-692.

21 In Oklahoma vond $82 \%$ van de wetgevers en $70 \%$ van de burgers van Oklahoma die voor het amendement stemden het noodzakelijk om een preventieve aanval uit te voeren tegen elke islamitische wet die Oklahoma infiltreert: J. Balou, 'Sooners vs. Shari'a: The Constitutional and Societal Problems Raised by the Oklahoma State Ban on Islamic Shari'a Law', Law and Inequality 2012, 310, p. 316-318. 
deze systemen bepalen wat is toegestaan en wat niet. ${ }^{22}$ En dit, nu, is de kern van de interactie tussen 'sharia' en het 'Westen'.

In Westerse staten en samenlevingen vormen moslims een minderheid met weinig of geen invloed op wat de meerderheid wil, of dat nu cultureel, juridisch of politiek is. Hoewel door critici van de islam en de sharia soms wordt gesuggereerd dat het Westen worstelt met een opkomende sharia (in Amerika wordt de term 'sluipende sharia' (creeping sharia) gebruikt), hoeven de Westerse normatieve systemen zich in werkelijkheid niet aan te passen of anderszins toe te geven aan de islamitische regels. Zelfs als men van mening zou zijn dat de Westerse normatieve systemen zich meer zouden móeten aan passen aan de regels van de islam, ${ }^{23}$ dan zouden dergelijke aanpassingen alleen gemaakt kunnen worden wanneer deze systemen daarvoor kiezen, en niet omdat moslims die zouden opleggen. Moslims die een islamitische regel van hun keuze willen toepassen, zijn altijd afhankelijk van de mogelijkheden, toestemmingen en verboden van de Westerse normatieve context.

Het lijkt er daarom op dat de verhouding tussen de regels van het Westen en de regels van de islam beschreven kan worden, in de woorden van M.B. Hooker, als de 'dominante' ten opzichte van de 'dienende' regels. ${ }^{24}$ Hoewel dit misschien vanzelfsprekend lijkt, is het van belang om dit te benadrukken, omdat de kwestie van de sharia versus het Westen vaak wordt besproken alsof het een conflict tussen twee gelijke entiteiten betreft. En dat is absoluut niet het geval. De machtsverhouding werkt namelijk zonder meer in het voordeel van het Westerse systeem: dat heeft de middelen en mogelijkheden om zijn wensen te laten prevaleren boven de voorstanders van islamitisch regels. Dit blijkt bijvoorbeeld uit de toenemende neiging in Europese landen om culturele praktijken te 'verdedigen' door middel van wetgeving, een verdediging die vaak gericht is tegen de regels van de islam, resulterend in wetten en verordeningen betreffende kledingvoorschriften (hoofddoek) of sociale interactie (handen schudden, boerka). Wat zich daarbij voltrekt is de omzetting van een cultureel-religieuze reactie in een politiek-juridische reactie.

22 Deze term is gebaseerd op de terminologie 'legal system' en 'legal culture', zoals gebruikt door een aantal wetenschappers: M. Chiba, 'Other Phases of Legal Pluralism in the Contemporary World', Ratio Juris 1998; M. van Hoecke \& M. Warrington, 'Legal Cultures, Legal Paradigms and Legal Doctrine: Towards a New Model for Comparative Law', International \& Comarative Law Quarterly 1998, 47; U. Mattei, 'Three Patterns of Law: Taxonomy and Change in the World's Legal Systems', American Journal of Comparative Law 1997, 5; D. Nelken, 'Comparing Legal Cultures', in: A. Sarat (red.), The Blackwell Companion to Law and Society, 2004, p. 113-130; C. Varga (red.), Comparative legal cultures, 1992.

23 Zoals wordt betoogd door M.-C. Foblets, J.-F. Gaudreault-Desbiens \& A. Dundes Renteln, The Response of State Law to the Expression of Cultural Diversity, 2010; M. Malik, Muslim Legal Norms and the Integration of European Muslims, European University Institute 2009; D. McGoldrick, 'Accommodating Muslims in Europe: From Adopting Sharia Law to Religiously Based Opt Outs from Generally Applicable Laws', Human Rights Law Review 2009; P. Shah, 'Transforming to Accommodate? Reflections on the Shari'a Debate in Britain', in: R. Grilloe.a. (red.), Legal Practice and Cultural Diversity, 2009, p. 73-92; B.S. Turner \& B.Z. Arslan, 'Shari'a and legal pluralism in the West', European Journal of Social Theory 2011, 139.

M.B. Hooker, Legal Pluralism: An Introduction To Colonial And Neo-Colonial Laws, 1975. 


\section{$5 \quad$ Beveiliging als derde reactie?}

De vorige paragraaf ging niet in op een derde en misschien wel de meest dominante hedendaagse reactie op regels van de islam, namelijk de veiligheidsreactie. 'Sharia' wordt als zodanig, of in bepaalde uitingen ervan, soms gezien als een bedreiging voor de rechtsorde, de sociale cohesie of de nationale veiligheid in het algemeen. De reactie is in dit geval niet van politiek-juridische of cultureel-religieuze aard, maar is er een van zelfbehoud of zelfs zelfverdediging. Is dit, naast de politiek-juridische en cultureel-religieuze reactie, een derde categorie Westerse reacties waarmee we rekening moeten houden?

Naar mijn mening is dat niet nodig, omdat deze reactie van een andere orde is. De politiek-juridische en cultureel-religieuze reacties komen voort uit sterk gekoesterde waarden. Veiligheid daarentegen is een zelfverdedigingsreactie; het is zelf geen waarde, of gebaseerd op een waarde, maar is een mechanisme dat dient om die waarden te beschermen. Dit is niet bedoeld om deze reactie af te wijzen als niet relevant voor de discussie die wij hier voeren. Ik houd me hier echter meer bezig met de analyse van onderliggende factoren (over wat voor soort sharia hebben we het, en wat is de aard van de reacties daarop vanuit de Westerse omgeving) dan met het beveiligingsbeleid dat al dan niet op een dergelijke analyse volgt. Daarom laat ik veiligheidsoverwegingen buiten dit model.

\section{Conclusie: een definitie van het Westen}

Op basis van het vorenstaande definieer ik het Westen in dit model als (a) een normatief politiek, juridisch en sociaal systeem dat (b) typische 'Westerse' geschiedenis, kenmerken, en waarden deelt, en (c) dat wordt opgelegd middels meerderheidscontrole. De Westerse reacties op regels van de islam kunnen vaak worden gereduceerd tot twee categorieën van reacties: de politiek-juridische reactie, die de waarden vertegenwoordigt die zijn vastgelegd in verdragen en grondwetten, en de cultureel-religieuze reactie, die de waarden vertegenwoordigt die het best kunnen worden samengevat als 'dat is hoe we de dingen doen, hier.'

Conflicten met de regels van de islam behoren meestal tot de laatste categorie: hoewel veel regels van de islam perfect in overeenstemming zijn met de Westerse politiek-juridische waarden, of daardoor worden toegestaan, worden ze vaak beschouwd als strijdig met cultureel-religieuze waarden. Ik ben van mening dat de meeste Westerse conflicten met de islam die het nieuws halen - met uitzondering van de met de islam gemotiveerde terroristische aanslagen - kwesties zijn die verband houden met sociale omgangsvormen. In sommige gevallen, zoals het boerkaverbod in Frankrijk en België en het shariaverbod in verschillende Amerikaanse staten, zijn deze inmiddels gelegaliseerd en daarmee onderdeel geworden van de politiek-juridische waarden.

\section{Deel III Reacties van moslims}

Het in dit artikel voorgestelde model is gebaseerd op een dialectiek: islamitische sociaaljuridische entiteiten willen volgens bepaalde regels van de islam leven, waar Westerse normatieve systemen vervolgens op reageren, wat op zijn beurt 
tegenreacties van moslims oproept. Deze tegenreacties zal ik in dit derde en laatste deel bespreken.

\section{Het effect op moslims}

De hiervoor besproken situaties laten zien dat de Westerse politiek-juridische reactie vaak gunstig is ten aanzien van de regels van de islam. Niettemin worden regels van de islam vooral beantwoord met een negatieve cultureel-religieuze reactie. De vermeende inbreuk van deze islamregels op cultureel-religieuze waarden wordt regelmatig als dusdanig ernstig ervaren dat het publiek of de politiek om bescherming van deze waarden vraagt, soms zelfs met een beroep op de nationale veiligheid.

Van de kant van de moslims kunnen we hierop twee reacties waarnemen. Aan de ene kant beroepen moslims in het Westen zich op de Westerse politiek-juridische waarden, soms zelfs meer dan hun niet-moslimse medeburgers. ${ }^{25}$ Dat is niet verwonderlijk, omdat deze waarden de vrijheid garanderen om te leven in overeenstemming met iemands religieuze en culturele eigenheden. Het zijn juist de Westerse politiek-juridische waarden die verregaande mogelijkheden bieden om te leven in overeenstemming met de regels van de islam. Dit is waar de aartsbisschop van Canterbury en de Lord Chief Justice van Engeland en Wales op wezen in hun toespraken in 2008.

Het is daarom niet verwonderlijk dat moslims in het Westen de Westerse reacties regelmatig beschouwen als het meten met twee maten: de vrijheden die het Westen omarmt worden beperkt zodra het gaat om de islam en moslims. ${ }^{26}$ Deze indruk van moslims wordt versterkt door initiatieven in sommige Westerse landen om bepaalde cultureel-religieuze waarden te legaliseren, waardoor ze worden opgetrokken tot het niveau van politiek-juridische waarden, zoals het verbod op minaretten in Zwitserland of het boerkaverbod in Frankrijk, België en Nederland.

\section{Het effect van Westerse reacties op de regels van de islam}

Moslims in het Westen zijn zich er terdege van bewust dat wat zij willen met betrekking tot de regels van de islam niet altijd wettelijk mogelijk is, en nog vaker problematisch is vanwege politieke, emotionele en culturele bezwaren. Veel moslims houden niettemin vast aan hun recht te mogen leven volgens de regels van de islam; sommigen eisen dat recht op agressieve wijze op, maar de meesten doen het in stilte. Ongeacht de toon waarop zij het doen, kunnen we vijf manieren identificeren waarop moslims omgaan met de regels van de islam wanneer zij worden geconfronteerd met een negatieve Westerse respons: instemming, toepassing, aanpassing, overeenstemming en berusting.

26 Er is (nog) geen wetenschappelijke literatuur om deze opvatting te ondersteunen, maar een snelle scan van internet laat zien dat dit sentiment breed wordt gedeeld door moslims. 


\subsection{Instemming}

Sommige regels van de islam worden in het geheel niet nageleefd door moslims in het Westen omdat daar bij hen geen behoefte aan bestaat, of omdat zij menen dat die regels niet van toepassing (meer) zijn. In deze gevallen zullen de moslims instemmen met Westerse afwijzing. Welke deze regels zijn, hangt af van de individuele moslim (sommigen zijn misschien helemaal niet religieus en wijzen bijna alle regels van de islam af), maar er lijkt een brede consensus te bestaan onder Westerse moslims dat de lijfstraffen die volgens de islam staan op bepaalde misdaden niet van toepassing kunnen of mogen zijn. ${ }^{27}$ Deze misdaden worden expliciet vermeld in de Koran en worden daarom als theologisch verplicht beschouwd. Toch zijn er geen aanwijzingen dat moslims in het Westen voorstander zouden zijn van de invoering van de lijfstraffen die daarop staan. Deze constatering wordt echter niet onderbouwd door enquêtes of ander onderzoek. ${ }^{28}$

\subsection{Toepassing}

Met betrekking tot sommige regels van de islam achten gelovige moslims geen compromis mogelijk: dergelijke regels moeten volgens hen volledig worden overgenomen en onvoorwaardelijk worden nageleefd. Deze regels, die betrekking hebben op de kern van de islamitische orthodoxie, zijn van tweeërlei aard: de meeste zijn van toepassing op de relaties tussen de gelovige en God (ibadat), en sommige op de relaties tussen mensen (mu'amalat). De ibadat zijn de regels met betrekking tot rituelen zoals gebed, vasten, slachting, begrafenis en kledingvoorschriften. In geval van de mu'amalat gaat het vooral om de regels van huwelijk en echtscheiding, en het verbod op rente.

Moslims die deze regels van de islam willen naleven, maar die daartoe niet in staat gesteld worden door hun omgeving, ervaren dat als een regelrechte belemmering van de vrijheid van hun religie. Om toch te kunnen voldoen aan deze regels zijn er diverse mogelijkheden. Sommige moslims onttrekken zich aan de omgeving die het voor hen zo lastig maakt en gaan leven in isolement, mogelijk binnen hun eigen gemeenschap, net als sommige van hun christelijke, joodse en andere orthodoxe collega's in het Westen dat hebben gedaan. Anderen wenden zich met wisselend succes tot de rechterlijke of wetgevende autoriteiten met een beroep op de vrijheid van godsdienst. Een derde optie is die waaraan extremisten de voorkeur geven, namelijk dat zij hun voorkeursregels van de islam op luide toon opeisen en bereid zijn tot dwang en zelfs geweld tegen moslims en niet-moslims.

\subsection{Aanpassing}

Moslims die zich houden aan een strikte naleving van de regels van de islam zijn niet bereid de minste aanpassing aan deze regels aan te brengen. Maar sommige

27 Deze misdaden zijn: diefstal, inname van alcohol, snelwegoverval, overspel en valse beschuldiging van overspel. Moord en afvalligheid zijn ook inbegrepen, maar niet specifiek in de Koran genoemd als misdaden.

28 Het PEW-onderzoek The World's Muslims: Religion, Politics and Society van 2013 vermeldt dat in Europese landen als Kosovo, Bosnië-Herzegovina en Albanië 36\% van de moslims voorstander is van strengere straffen 'op islamitische grondslag' (p. 23 van het PEW-rapport). 
gelovige moslims staan open voor nieuwe interpretaties van die regels. Hier spelen de recent ontwikkelde wetenschap van fiqh al-aqalliyat ('islamitisch recht voor minderheden') ${ }^{29}$ en het begrip maqasid al-sharia ('doeleinden van de sharia') een belangrijke rol. ${ }^{30}$ Een paar voorbeelden kunnen als illustratie dienen:

a Een moslimwerknemer in een fastfoodrestaurant vroeg of hij gerechten met varkensvlees mocht verkopen. In een fatwa (theologische uitspraak) werd hem verteld dat het verkopen en hanteren van varkensvlees in de regel verboden is en dat hij moet proberen werkafspraken te maken om dit te voorkomen. Als dit niet mogelijk was, zou hij een andere baan moeten zoeken. Maar als hij geen ander werk zou kunnen vinden, dan moest hij blijven werken tot hij een andere bron van inkomsten had gevonden. ${ }^{31}$

b Mogen moslims deelnemen aan de verkiezingen en aan het bestuur van een land waar niet-moslims de meerderheid vormen en de dienst uitmaken? De islamitische rechtswetenschap uit de klassieke periode zegt daar niets over om de simpele reden dat deze situatie niet bestond op het moment dat deze wetenschap werd ontwikkeld. Daarom wordt gekeken of de islam andere aanknopingspunten biedt. Aan de ene kant was er de situatie waarin de Profeet Mohammed zijn volgelingen naar het christelijke koninkrijk van Ethiopië stuurde om vervolging in Mekka te ontvluchten. Daarmee erkende de Profeet dus de soevereiniteit van een christelijk vorst over moslims. Aan de andere kant hanteert de islamitische rechtswetenschap de regel dat 'de islam heerst en niet overheerst kan worden', met andere woorden: een moslim mag nooit worden onderworpen aan een niet-islamitische autoriteit. De voorstanders van 'islamitisch recht voor minderheden' introduceerden echter een alternatieve overweging, namelijk het 'belang' (maslaha) van de moslim. Volgens de islamitische theologie ligt dit belang ten grondslag aan alle regels, en daarom stelden de islamitische minderheidsjuristen dat deelname van moslims aan verkiezingen en bestuur in een niet-islamitisch land toegestaan of zelfs noodzakelijk is 'indien de belangen van moslims daarmee gediend worden'. ${ }^{32}$

c In een controversiële uitspraak verklaarde de Europese Raad voor Fatwa en Onderzoek dat een rentedragende hypotheek bij uitzondering was toegestaan voor moslims die in het Westen wonen, met het volgende argument: omdat het bijna onmogelijk is om een huis in het Westen te kopen zonder een hypotheek, en het kopen van een huis een manier is om naar betere buurten te verhuizen, zou het hypotheekverbod de moslims van de mogelijkheid beroven om hun woon- en levensomstandigheden te verbeteren. Dit zou volgens de

29 Zie literatuurverwijzing onder voetnoot 9 in M.S. Berger, 'Sharia en het Westen (I)', Tijdschrift voor Religie, Recht en Beleid 2019, 3.

30 J. Auda, Maqasid al-Sharia as Philosophy of Islamic Law: A Systems Approach, 2008; D. Hussain, 'Muslim Political Participation in Britain and the "Europeanisation" of Fiqh', Die Welt des Islams 2004, 376; M.H. Kamali, Maqasid al Sharia Made Simple, The International Institute of Islamic Thought 2009. Zie ook T. Ramadan, Radical Reform. Islamic Ethics and Liberation, 2009.

31 European Council of Fatwa and Research, 'Fatwa nr. 14, 1999 (second session)' in: Altikriti \& AlUbaydi (red.) Fatwas of European Council for Fatwa and Research, Islamic Inc., geen datum.

32 A. Caeiro, 'The European Council for Fatwa and Research', paper presented at the Fourth Mediterranean Social and Political Research Meeting, Florence 2003. 
Raad in strijd zijn met het primaire doel van de sharia, namelijk moslims in staat stellen om vooruit te komen in het leven. ${ }^{33}$

Dit zijn drie voorbeelden van een meer liberale interpretatie van de regels van de islam. Andere moslimgeleerden kunnen echter op basis van dezelfde uitgangspunten tot andere conclusies komen. ${ }^{34}$ Deze diversiteit in meningen is verwarrend voor sommige moslims (evenals voor de meeste niet-moslims), maar kan ook bezien worden als typerend voor de flexibele aard van de sharia: de islamitische rechtswetenschap accepteert immers dat meer dan één interpretatie mogelijk is, afhankelijk van tijd en omstandigheden, en het is aan de gelovigen om de wetenschappelijke interpretatie te kiezen die het beste bij hun persoonlijke overtuigingen past.

\subsection{Overeenstemming}

Een andere vorm van aanpassing van islamitische regels aan de Westerse context is wanneer de islamitische regel wordt beschouwd in overeenstemming te zijn met het Westerse rechtssysteem. In dat geval is er geen aparte aanpassing van die islamregel nodig en hoeft deze ook niet apart toegepast te worden, aangezien de Westerse regels daar al in voorzien. Zo is bijvoorbeeld gesteld dat een aparte islamitische huwelijkssluiting eigenlijk niet nodig is, omdat de voorwaarden daarvan gelijk zijn aan die van de burgerlijke huwelijkssluiting (aanbod en acceptatie van het huwelijk in aanwezigheid van twee getuigen), ${ }^{35}$ met dien verstande dat de getuigen bij het islamitisch huwelijk moslim moeten zijn. ${ }^{36}$

Evenzo wordt wel betoogd dat de echtscheiding volgens Westers recht niet wezenlijk anders is dan een islamitische scheiding (talaq): hoewel de Westerse scheiding door de rechter wordt uitgesproken, is zowel de Westerse als de islamitische scheiding in feite een eenzijdige handeling, aangezien de scheiding kan worden verkregen door de enkele wens van een van de echtgenoten, zonder dat nadere wettelijke voorwaarden worden gesteld. Een belangrijk verschil is natuurlijk dat in de Westerse rechtssystemen beide echtgenoten dit eenzijdige recht op echtscheiding hebben, terwijl de islamitische scheiding het exclusieve recht is van de echtgenoot. Maar dit verschil kan opgeheven worden als de moslimman gebruikmaakt van de islamitische regel dat hij zijn echtgenote kan machtigen om ook gebruik te maken van dit scheidingsrecht. ${ }^{37}$

33 A. Caeiro, 'The social construction of shari'a: bank interest, home purchase, and Islamic norms in the West', Die Welt des Islams 2004.

34 Zie o.a. M.S. Berger, 'Buying houses, donating organs and fighting wars - the changing role of muftis', Recht van de Islam 2011; G.R. Bunt, Islam in the Digital Age: E-jihad, Online Fatwas and Cyber Islamic Environments, Pluto Press 2003; B. Gräf \& J. Skovgaard-Petersen (red.), Global mufti : the phenomenon of Yusuf al-Qaradawi, 2009; V. Šisler, 'The Internet and the Construction of Islamic Knowledge in Europe', Masaryk University Journal of Law and Technology 2007, p. 205-217.

35 Aldus bijv. moefti Ebrahim Deassai (vermeld in V. Sisler, 'European courts' authority contested? The case of marriage and divorce fatwas on-line', Masaryk University Journal of Law and Technology 2009, 51, p. 65-66).

36 De aanwezigheid van een imam is gebruikelijk, maar geen vereiste volgens de regels van de islam.

37 Dit is de machtiging (tafwid) van de talaq. 
Een laatste voorbeeld van overeenstemming zijn internationale betrekkingen en internationaal recht. De regels die daar gelden zijn niet wezenlijk anders of strijdig met de regels van de islam. Hier zou uit afgeleid kunnen worden dat zij eigenlijk hetzelfde zijn. Deze logica wordt door alle moderne moslimstaten stilzwijgend erkend. ${ }^{38}$ En men zou hier zelfs een stap verder in kunnen gaan, zoals in 1995 in Egypte gebeurde: toen een team van vooraanstaande islamitische geestelijken verklaarde dat $95 \%$ van de Egyptische wetten 'niet strijdig is met de sharia', concludeerde de staat dat deze $95 \%$ feitelijk dus gelijk was aan sharia ${ }^{39}$ (cursivering van mij; MB).

\subsection{Berusting}

Waar in de voorgaande voorbeelden steeds sprake is van enige mate van eigen keuze, zijn er ten slotte ook situaties waarin moslims noodgedwongen moeten erkennen dat bepaalde regels van de islam niet kunnen worden toegepast of nageleefd, simpelweg omdat ze niet worden toegestaan door de Westerse samenleving waar zij wonen. Dat geldt bijvoorbeeld voor Koranische lijfstraffen, kindhuwelijken of strenge vormen van sekse-segregatie. In bepaalde Westerse landen gelden bovendien specifieke verboden, zoals een wettelijk verbod op gezichtssluiers of ritueel slachten. Voor de moslims die dergelijke regels wel zouden willen navolgen, rest de keuze tussen berusting in dat verbod of emigratie naar een land waar dit wel mogelijk is. Voor bepaalde regels zou een tussenweg kunnen zijn dat zij worden nageleefd in de kleinere kringen van hun families of gemeenschappen, net als het geval is in sommige orthodoxe joodse en christelijke gemeenschappen in het Westen. Maar zelfs in die situaties zal altijd de grens worden gesteld door het nationale strafrecht.

\section{Strategieën}

De dynamiek tussen 'sharia' en 'het Westen' manifesteert zich ook op onverwachte manieren, namelijk wanneer individuele moslims een van de twee systemen gebruiken, of ze juist tegen elkaar uitspelen, om hun eigen gelijk te halen.

In het model 'sharia en het Westen' zijn we uitgegaan van 'informele juridische praktijken', dat wil zeggen dat naleving van de regels van islam gebeurt zonder enige handhaving anders dan vanuit het individu of de gemeenschap. Deze regels en hun handhaving vormen derhalve een intrinsiek onderdeel van de sociale dynamiek en strategieën van moslimgemeenschappen. Het instellen van een zaak tegen iemands echtgenoot voor een Britse shariacouncil heeft misschien formeel geen juridisch effect, maar de shaming and blaming kan binnen de gemeenschap wellicht betere resultaten opleveren dan welke rechtbank ook. ${ }^{40}$ Evenzo kunnen moslimmeisjes de keuze van hun ouders voor een huwelijkspartner omzeilen door

38 M.S. Berger, 'Islam and Islamic Law in International Relations', in: M.-L. Frick \& A.Th. Mueller (red.), Islam and International Law. Engaging Self-Centrism from a Plurality of Perspectives, 2013, p. 392, 411.

39 M.S. al-`Ashmawi, al-Shari'a al-Islamiyya wa al-Qanun al-Masri, 1996, p. 10.

40 S. Bano, 'Muslim Family Justice and Human Rights: The Experience of British Muslim Women', Journal of Comparative Law 2007, 38. 
hen te confronteren met een stiekem gesloten islamitisch huwelijk met een partner naar keuze van het meisje. ${ }^{41}$

Soortgelijke strategieën kunnen ook gebruikmaken van de formele juridische structuren. Voor sommige moslims kan dit zijn om juist hun identiteit te benadrukken, zoals bijvoorbeeld het geval is met de vele hoofddoekzaken die moslims voor de rechtbanken in heel Europa hebben gevoerd. ${ }^{42}$ Maar de burgerlijke rechtbank kan ook ingeschakeld worden om juist de werking van islamitische regels die binnen de gemeenschap worden opgelegd, ongedaan te maken. Het zijn voornamelijk moslimvrouwen die deze strategieën aanwenden. Zo zijn vrouwen die binnen de informele structuur van hun gemeenschap geen aanspraak konden maken op de bruidsgave waar zij volgens de islam recht op hebben na echtscheiding, erin geslaagd om burgerlijke rechtbanken te laten erkennen dat deze bruidsgave opeisbaar is als onderdeel van een burgerrechtelijke overeenkomst. ${ }^{43}$ En de moslimvrouw die is gescheiden voor de burgerlijke rechter, maar wiens man weigert om ook volgens religieus recht van haar te scheiden, kan in een aantal Westerse landen haar man om die reden veroordeeld krijgen voor een onrechtmatige daad. ${ }^{44}$

Onderzoek naar de omvang en aard van deze strategieën is beperkt, maar het lijkt erop dat dit gebruik (én misbruik) door individuele moslims van zowel de regels van de islam als het Westerse rechtssysteem niet incidenteel is. Verder onderzoek op dit gebied is welkom, omdat het een nauwkeuriger en completer beeld zou geven van de aard van de sharia in het Westen, en met name van de dialectiek met zijn Westerse omgeving.

\section{Slotopmerkingen}

Het begrip 'sharia in het Westen' is ingeburgerd in zowel maatschappelijke als politieke en wetenschappelijke kringen, maar de termen 'sharia' en 'het Westen' laten zich nog steeds moeilijk omschrijven. Des te opvallender is dat de combinatie van deze twee termen met zulke vanzelfsprekendheid wordt gebruikt in het publieke en politieke debat, en zelfs in het juridisch jargon, dat toch bij uitstek

41 A. Moors, 'Unregistered Islamic Marriages: Anxieties about Sexuality and Islam in the Netherlands', in: M.S. Berger (red.), Applying Sharia in the West. Facts, Fears and the Future of Rules of Islam on Family Relations in the West, 2013.

42 Malik2009.

43 U. Günther, M. Herzog \& S. Müssig, 'Researching Mahr in Germany: A Multidisciplinary Approach', Review of Middle East Studies 2015, 23; N. Yassari, 'Understanding and Use of Islamic Family Law Rules in German Courts: The Example of the Mahr', in: M.S. Berger (red.), Applying Sharia in the West. Facts, Fears and the Future of Rules of Islam on Family Relations in the West, 2013.

44 Zie voor Nederland: M. Berger, 'Het afdwingen van een islamitische verstoting', Tijdschrift voor Religie, Recht en Beleid 2011, 2; P. Kruiniger, Niet langer geketend aan het huwelijk! Juridische instrumenten die huwelijkse gevangenschap kunnen voorkomen of oplossen, Maastricht 2018. In het Verenigd Koninkrijk is het probleem opgelost door de Divorce Religious Marriages Act 2002 (J. Caroll. 'Muslim women and "Islamic divorce" in England', Journal of Muslim Minority Affairs 1997. In Nederland wordt een dergelijke wet in 2020 verwacht (zie de 'Overwegende ...' in dit nummer van Tijdschrift voor Religie, Recht en Beleid). 
het terrein is waar nauwkeurigheid van terminologie wordt vereist. Het model dat in dit artikel wordt gepresenteerd, biedt een analytisch hulpmiddel dat ons antwoorden op en inzichten in drie vragen geeft: wat is de sharia die deze moslims in het Westen willen en beoefenen, in hoeverre kunnen en mogen ze dit doen in de Westerse omgeving waarin zij leven, en hoe reageren Westerse moslims op de mogelijkheden en beperkingen die zij hebben in de naleving van islamitische regels?

Vanuit een Westers perspectief zijn de antwoorden op deze vragen zowel zorgelijk als geruststellend. De zorg heeft te maken met het feit dat een toenemend aantal moslims in het Westen in overeenstemming met de regels van de islam wenst te leven. Deze zorg wordt vergroot door het feit dat hardvochtige vormen van sharia worden toegepast door een aantal moslimstaten en islamitische organisaties, en dat terroristische aanslagen worden gepleegd door moslims die de sharia inroepen om hun acties te rechtvaardigen. Daarentegen bieden de antwoorden ook enige geruststelling, omdat de vormen van sharia die worden toegepast door de meerderheid van de moslims in het Westen beperkt zijn tot drie domeinen: religieus ritueel, familierecht en financieel recht, en interactie met de niet-moslimomgeving. In dit opzicht is er weinig verschil tussen de islam en andere religieuze gemeenschappen in het Westen.

Als we de dynamiek van 'sharia in het Westen' recht willen doen, dan is het nodig om de terminologie te herzien. Om een aantal redenen heb ik voorgesteld om de term 'sharia' te vervangen door 'regels van de islam'. In het geval van het Westen zijn deze regels geen geschreven wet, maar is het een reeks regels die door moslims op een autonome manier worden toegepast en die in continue interactie verkeren met 'het Westen'. We hebben het Westen vervolgens gedefinieerd als een normatief dominant systeem, niet alleen in juridische zin, maar ook politiek, sociaal en cultureel. Vanuit deze dominante positie komt het Westen met twee reacties: politiek-juridisch en cultureel-religieus.

Het model laat zien dat veel regels van de islam zoals toegepast door moslims in het Westen niet in tegenspraak zijn met wetten, grondwetten of politieke waarden zoals vrijheid of gelijkheid. De meeste negatieve reacties op de regels van de islam zijn namelijk vooral van cultureel-religieuze aard, gedefinieerd als het onderbuikgevoel van 'dit is niet hoe we de dingen hier doen'. Deze reactie lijkt in toenemende mate voorrang te krijgen op politiek-juridische overwegingen.

De voortdurende dialectiek tussen de regels van de islam en het Westen heeft tot gevolg dat beide zijden worden gedwongen om duidelijk te maken welke regels als essentieel worden beschouwd, en om strategieën te ontwikkelen waarmee deze regels gehandhaafd kunnen worden en oplossingen worden gevonden in gevallen waarin ze met elkaar in tegenspraak zijn. Het model stelt ons in staat om een proces te bestuderen dat dynamischer is dan men in eerste instantie zou veronderstellen, en dat beide partijen confronteert met essentiële vragen over hun juridische en religieuze waarden en over de rol van religie in Westerse rechtsstelsels. In deze voortdurende dialectiek zie ik een aantal zorgwekkende ontwikkelingen waarvan ik er twee zal noemen. Met betrekking tot de Westerse moslims gaat de toename van hun religiositeit gepaard met een intense focus op de regels van religie. Deze trend, die ik 'juridisering van religie' noem, leidt de moslims weg van de 
spirituele dimensies van de islam en reduceert hun leven in het Westen tot de rigide dualiteit van haram-halal (verboden-toegestaan). In het geval van niet-islamitische westerlingen maak ik me zorgen over de manier waarop cultureel-religieuze waarden worden voorgesteld of ervaren als waarden die bedreigd worden en daarom bescherming behoeven. Steeds vaker wordt wetgeving ingezet om deze bescherming te bieden, en op die manier worden gedragingen verboden die anders volgens politiek-juridische waarden zouden zijn toegestaan. Hoewel in sommige gevallen maatregelen inderdaad gerechtvaardigd kunnen zijn vanwege staatsveiligheid, meen ik dat het Westen door deze koers te volgen niet zozeer een tegenstander heeft in de islam, maar in zijn eigen waarden: want wil het Westen leven volgens de kernwaarden van zijn politiek-juridische waarden zoals vastgelegd in grondwetten en internationale verdragen, of wil het zijn cultureelreligieuze waarden opleggen aan iedereen die woonachtig is in het Westen? 